\title{
Giovanni Baronzio's 'Crucifixion': analytical approaches and art historical considerations
}

\author{
Svetlana Gasanova ${ }^{1 *} \mathbb{D}$, Nikolas Bakirtzis ${ }^{1}$, Dominique Levif-Martos² and Sorin Hermon ${ }^{1}$
}

\begin{abstract}
The small panel of the 'Crucifixion' attributed to Giovanni (da Rimini) Baronzio is a perfect example of the artistic achievements of the so-called School of Rimini. Baronzio, active between 1320 and 1350, was one of the most important painters of a group of artists working in Rimini during the first half of the 14th-century whose work was heavily influenced by the work of Giotto di Bondone (1267-1337), characterized by Gothic and Byzantine influences. The panel, with an estimated date in the end of the $1320 \mathrm{~s}$, represents a popular iconographic theme during this period and was painted in tempera and gold on wood. Non-invasive analytical approaches have revealed a rich history of interventions, re-touching and restorations, which allows for some interesting observations and considerations in regard to the work's history. The applied analytical methods and the related art historical observations and interpretations are the focus of the present article. In order to avoid micro-sampling, a non-invasive methodological approach integrating spectroscopic ( $\mu$-X-ray fluorescence spectroscopy, Fourier transform infrared spectroscopy), imaging (UV, X-ray radiography, infrared reflectography) and digital microscopy techniques was applied. This study aimed at the identification of the work's original materials and techniques, its state of preservation and the complex history of interventions. Results showed that while original materials of the painting conform with those used by artists in fourteenth century Renaissance Italy, there are multiple later interventions both as smallscale inpainting as well as extensive overpainting of various parts of the original Crucifixion composition. Careful consideration of these interventions can shed light to aspects of the panel's history of preservation as well as on issues of stylistic or compositional 'corrections'- always an interesting dimension of the changing perceptions of works of art through time.
\end{abstract}

Keywords: Crucifixion, Giovanni da rimini baronzio, Panel painting, Pigment analysis, Restoration

\section{Introduction}

This study addresses aspects of the close study and understanding of the long history of interventions on works of art, specifically panel paintings. Advances in science and technology have enriched our capacity to analyse the materiality of art and thus, we are now able to better trace the original work as well as the 'touch' of several hands through the history of panel paintings as they changed owners, adhered to changes in style

\footnotetext{
*Correspondence: s.gasanova@cyi.ac.cy

${ }^{1}$ Andreas Pittas Art Characterization laboratories, APAC, Science and Technology in Archaeology and Culture Research Center, STARC, The Cyprus Institute, Nicosia, Cyprus

Full list of author information is available at the end of the article
}

and taste, or suffered in their preservation condition due to neglect and time. There is a range of analytical methods and instrumentation to map the materials and the technique of artists as well as to securely trace the repainting efforts that followed. A great number of paintings, among them many masterpieces, feature significant retouching and repainting thus sparking a debate on the concept of the original work of art. What is new, is that we can now measure post-original interventions with an array of scientific methods.

Nevertheless, our ability to study the layered stratigraphy of paintings permits the re-evaluation of the importance of these interventions. Whether restorations or 'corrections', they are an integral part of paintings' artistic and cultural value. Although art

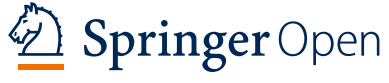

(c) The Author(s) 2020. This article is licensed under a Creative Commons Attribution 4.0 International License, which permits use, sharing adaptation, distribution and reproduction in any medium or format, as long as you give appropriate credit to the original author(s) and the source, provide a link to the Creative Commons licence, and indicate if changes were made. The images or other third party material in this article are included in the article's Creative Commons licence, unless indicated otherwise in a credit line to the material. If material is not included in the article's Creative Commons licence and your intended use is not permitted by statutory regulation or exceeds the permitted use, you will need to obtain permission directly from the copyright holder. To view a copy of this licence, visit http://creativeco mmons.org/licenses/by/4.0/. The Creative Commons Public Domain Dedication waiver (http://creativecommons.org/publicdomain/ zero/1.0/) applies to the data made available in this article, unless otherwise stated in a credit line to the data. 
historians and conservators have been obsessively focused on the quest for the 'original' work, celebrated as the starting point of artistic creation and, of course, the direct record of the artist's technique and painterly synthesis, 'post-original' interventions are particularly important. They mirror choices and actions taken to restore or to re-write visual compositions which can help us to better understand the impact, reception, market worth and cultural value of paintings through time.

The small panel of the 'Crucifixion' attributed to Giovanni (da Rimini) Baronzio is a perfect example of the artistic achievements of the so-called School of Rimini (Fig. 1) [1]. Giovanni Baronzio [2], active between 1320 and 1350, is considered to be amongst the leaders of a group of artists working in Rimini during the first half of the fourteenth century $[3,4]$; the artistic group largely defined by the stylistic relation of their work to the art of, maybe the best-known artist of the early Renaissance, Giotto di Bondone (1267-1337 [5]). Giotto travelled to Rimini in the beginning of the fourteenth century, specifically in 1303, painted his famous Crucifixion of Rimini and also a fresco cycle in the church of San Francesco, which unfortunately does not survive today.
The Rimini-school artists came in direct contact with Giotto's work and were influenced by his unconventional for his time style combining late Gothic and Byzantine characteristics and his achievements towards naturalism, three-dimensional forms and geometrical perspective.

The Crucifixion panel [1], with an estimated date in the end of the $1320 \mathrm{~s}$, represents maybe the most popular iconographic theme in this period and was painted in tempera and gold on wood. The compositional and stylistic details of the painting reflect the direct influence of Giotto on the Rimini school. The balanced organization of the composition based on the spatial arrangement of represented figures is a clear indicator of the artist's stylistic sources. The composition is dominated by the central figure of crucified Christ, set against a golden background and fully aligned with the vertical axis of the pointed upper part of the panel. He is flanked by the figures of two angels flying in distress towards him. The one to his right carries a bowl, presumably to collect his blood flowing from the wound inflicted in his side by a soldier's spear. The kneeling figure of Mary Magdalene is clutching the base of the Cross, almost kissing Christ's feet, as she looks up to him commiserating with his pain. To Christ's right is his mother, the Virgin Mary,
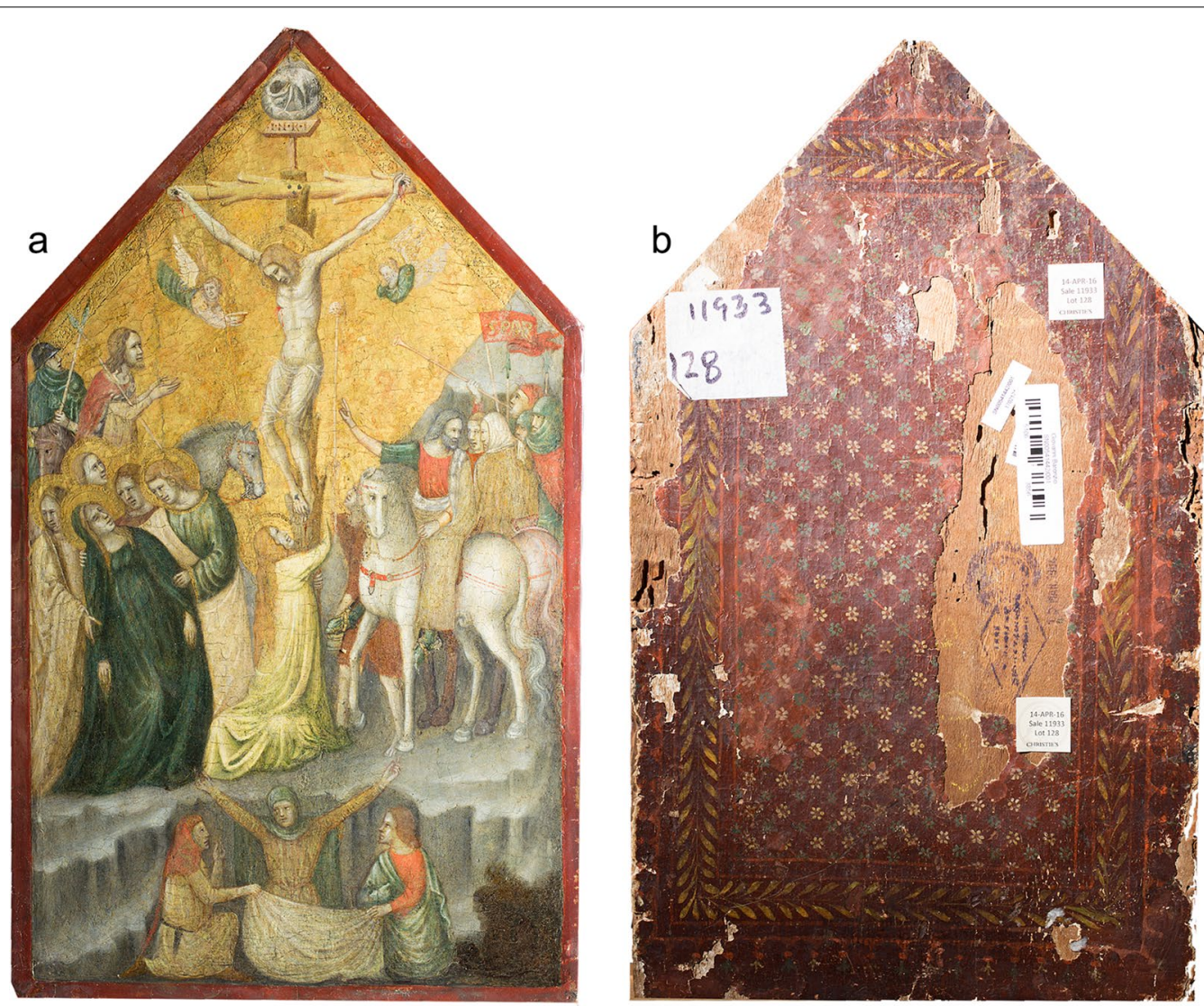

Fig. 1 Crucifixion by Baronzio: a front side, $\mathbf{b}$ back side 
represented fainting and being supported by John the Evangelist and other haloed mourning figures. Behind them, a bearded rider, possibly Longinus, accompanied by a solder turns to Christ with his two hands gesturing in prayer. To Christ's left is a group of riders and soldiers playing trumpets and carrying banners, among them a flag with the letters "SPQR". The riders seem to be conversing as the central rider figure points to Christ on the Cross. In the foreground, right under the figure of Mary Magdalene is a group of three kneeling figures. The central one, raises both arms in a gesture of grief while the other two figures hold and stretch a white sheettheir role in the narrative of the composition is not clear.

A series of analytical methods has been applied in order to evaluate the overall state of conservation of the panel, identify the artist's materials and techniques and document various phases of interventions. The applied non-invasive approach included digital microscopy, X-ray fluorescence spectroscopy, imaging under ultraviolet and infrared light, X-ray radiography and fourier-transform infrared spectroscopy.

\section{Materials and methods}

The Crucifixion was initially examined with X-rays at the Mediterranean Hospital of Limassol. The X-ray radiography image was recorded in transmission mode with a copper anode at $30 \mathrm{kV}, 500 \mu \mathrm{A}$ and $20 \mathrm{~ms}$, using a DX-D 40G, Agfa, $35 \times 45 \mathrm{~cm}$ detector.

The surface of the Crucifixion was photographed at various magnifications $(35 \times-2500 \times)$ with a Hirox KH8700 digital microscope equipped with a MXG2500REZ revolver zoom lens. A non-contact MXG2016X lens was used to photograph the painting's surface at low magnification $(20 \times-160 \times)$. In order to avoid specular reflection, when using the low magnification lens, the angle between the incident light and the surface was set at $45^{\circ}$.

The Ultraviolet images were recorded with a Canon EOS 5D Mark II Full Frame camera. The painting was illuminated with two UV lamps filtered and centered at $365 \mathrm{~nm}$. Infrared images were recorded with a Musis multispectral camera at $1000 \mathrm{~nm}$.

Fourier Transform Infrared spectra were recorded with an Agilent 4300 handheld spectrometer in Diffuse Reflectance and an Attenuated Total Reflectance modes. The spectral range was $650-4000 \mathrm{~cm}^{-1}$.

$\mathrm{X}$-ray fluorescence spectra were collected with an Artax $200 \mu \mathrm{XRF}$ using a $0.65 \mathrm{~mm}$ collimator, a Mo anode, $50 \mathrm{kV}, 700 \mu \mathrm{A}, 30 \mathrm{~s}$, helium flush for the better detection of the low-Z elements and a Mo filter $(12.5 \mu \mathrm{m})$. The filter is used in order to separate the signal of sulfur coming from the pictorial and ground layers and molybdenum from the anode material (Mo $\mathrm{L} \alpha$ at $2.29 \mathrm{keV}$ and $\mathrm{S} \mathrm{K} \alpha$ at $2.31 \mathrm{keV}$ ). The spectra were recorded with Spectra 5.3 software and processed with OriginPro 2015.

\section{Results and discussions Painting support}

The Crucifixion is painted on a wooden panel. The wood surface on both sides is prepared with a white ground layer. As wood absorbs moisture, the backside of the panel is covered with a thicker ground layer to reduce deformations. The white ground layer on the front side is mainly composed of calcite $\left(\mathrm{CaCO}_{3}\right)$ and a silicate material with small admixtures of gypsum $\left(\mathrm{CaSO}_{4} \cdot 2 \mathrm{H}_{2} \mathrm{O}\right)$. Commonly, the panel paintings are prepared with a layer of gypsum. In the case of Crucifixion, the use of calcite could be explained by its higher stability to deformations of the support compared to gypsum. XRF spectrum taken from a fragmented edge exposing the white ground shows intense $\mathrm{Si}, \mathrm{S}, \mathrm{K}$, $\mathrm{Ca}, \mathrm{Zn}$ and $\mathrm{Sr}$ lines (Fig. 2a). The nature of the calcium compound was concluded on the basis of the FTIR results, which detected strong calcite bands at 1415,870 , $710 \mathrm{~cm}^{-1}$ (Fig. 2b) as well as combination bands at 1792 and $2507 \mathrm{~cm}^{-1}$ (Fig. 2c). The low intensity sulfate bands at $665,1002,1105 \mathrm{~cm}^{-1}$ as well as $\mathrm{OH}$ bands at 1620 , $3240,3400 \mathrm{~cm}^{-1}$ suggest traces of gypsum. The silicate material is identified by $\mathrm{Si}-\mathrm{O}-\mathrm{Si}$ bands at $1025 \mathrm{~cm}^{-1}$ and a doublet at 795 and $775 \mathrm{~cm}^{-1}$. The other elements detected with $\mathrm{XRF}-\mathrm{Fe}, \mathrm{Zn}, \mathrm{Pb}, \mathrm{K}, \mathrm{Mn}$-demonstrate very low intensity and are likely related to impurities in the ground layer or contamination of the examined spot due to the proximity to the coloured areas. At the same time, the low intensity $\mathrm{Pb}$ lines are likely related to admixtures of lead white $\left(2 \mathrm{PbCO}_{3} \cdot \mathrm{Pb}(\mathrm{OH})_{2}\right)$.

The white preparation layer on the back side has a different composition compared to the one of the front side as it is mainly composed of gypsum with admixtures of calcite. The XRF spectrum shows much higher intensity of $\mathrm{S}$ and $\mathrm{Sr}$ lines compared to the spectrum of the white ground of the front side (Fig. 2a). FTIR spectrum demonstrates strong $\mathrm{SO}_{4}$ bands at 665, $1105,1002 \mathrm{~cm}^{-1}$ and $\mathrm{OH}$ bands at 1620, 1680,3240, $3400,3550 \mathrm{~cm}^{-1}$ confirming the presence of gypsum (Fig. 2b). Low intensity $\mathrm{CO}_{3}$ bands can be detected at $870,710 \mathrm{~cm}^{-1}$ and $2507 \mathrm{~cm}^{-1}$. Compared to the white ground of the front side, the one of the back side does not demonstrate any evidence of silicate materials as no $\mathrm{Si}$ lines or $\mathrm{Si}-\mathrm{O}-\mathrm{Si} / \mathrm{Si}-\mathrm{O}-\mathrm{Al}$ bands can be seen on XRF or FTIR spectra, respectively. 


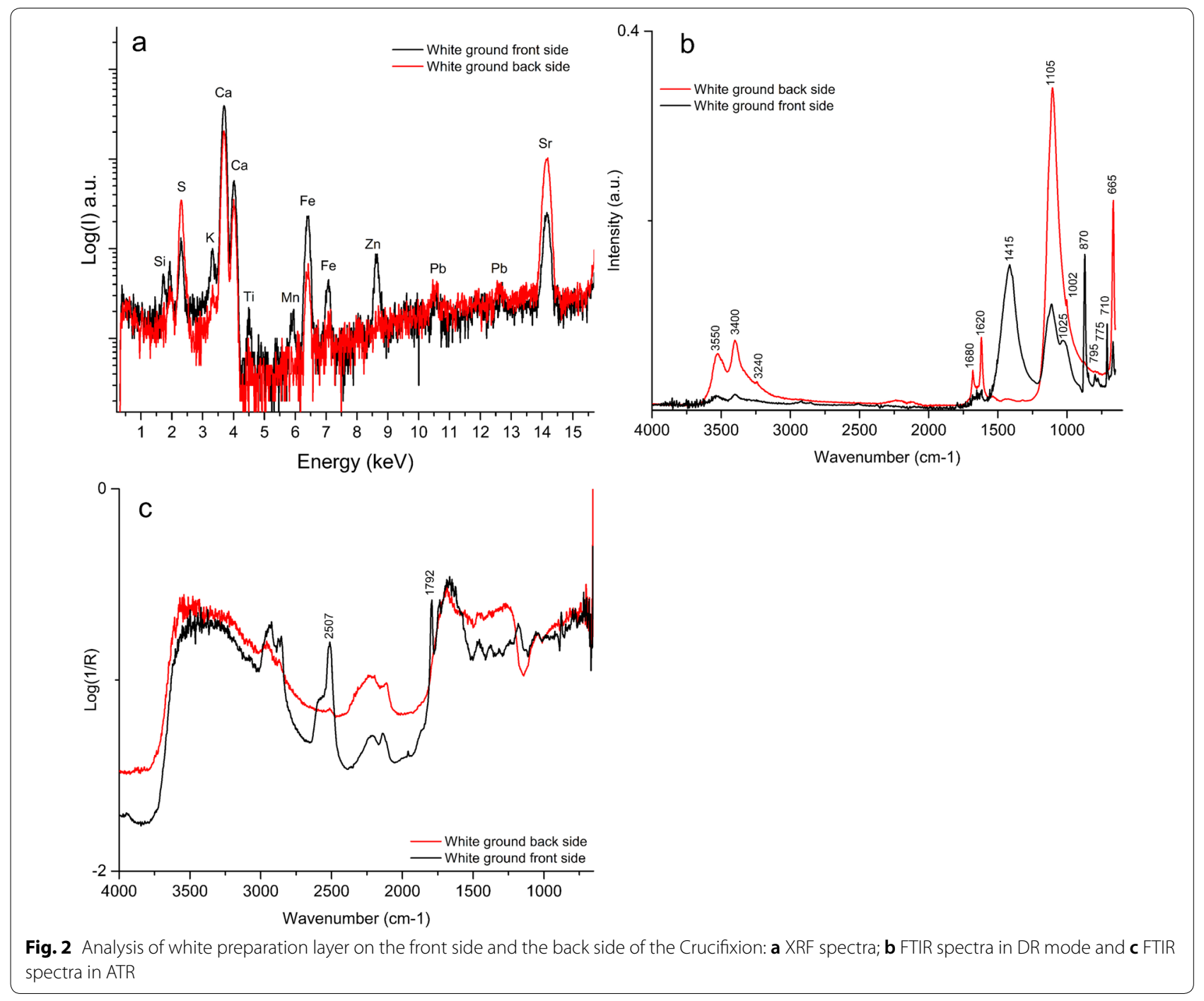

\section{Pigments of the original composition Gold gilding}

The Crucifixion has gold gilded areas on the background of the main composition and on the haloes of the saints. Remnants of metal can also be seen on the inscription "SPQR" (an abbreviation for Senātus Populusque Rōmānus, The Roman Senate and People) on the red flag, bridles of the grey horse and the stirrups.

The gold gilding in the background is obtained by applying gold leaves on a red preparation layer (Fig. 3a), the technique known as water gilding. The XRF spectra taken from this area (Fig. 3b) are dominated by gold $\mathrm{Au})$ lines. The XRF spectra of the red preparation layer suggest red ochre (red iron oxide $\mathrm{Fe}_{2} \mathrm{O}_{3}+$ clay) due to the $\mathrm{Fe}, \mathrm{Si}, \mathrm{Ti}$ and $\mathrm{Mn}$ lines. The spectrum of the red preparation also shows much more intense $\mathrm{Pb}$ lines than the one of the white ground suggesting admixtures of a $\mathrm{Pb}$-containing compound in the preparation layer, which can be identified as minium $\left(\mathrm{Pb}_{3} \mathrm{O}_{4}\right)$ as no evidence of lead white was observed with microscopy. A mixture of minium with red ochre for preparation of gold gilded areas has already been reported in a XV century Italian painting [6].

The XRF analysis of metal traces on the stirrups, bridles and the dresses shows the same results as gold gilding on the background. In these cases, the gold leaves were applied directly on the paint layer with no intermediate red preparation. The barely detectable traces of metal suggest that only small parts, likely the highlighted drapery folds, were decorated with gold gilding. An interesting feature was detected in the region of the red decorative belt of the white horse. Close microscopy observations detected traces of gold gilding around the tip of the belt. Purple colour can be seen on spots, where gilding is currently missing (Fig. 3c). The purple particles are of very fine size, which makes them undistinguishable 

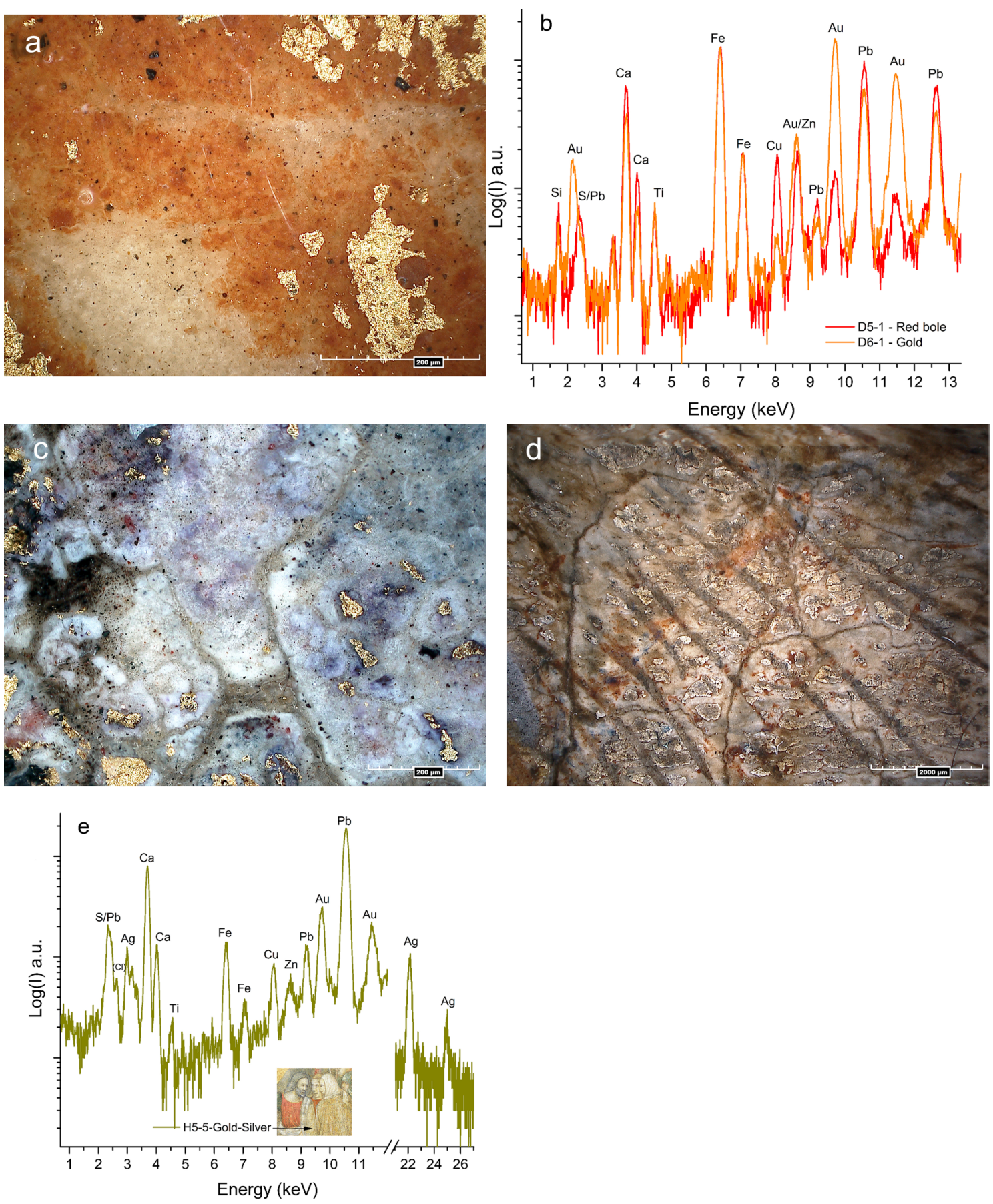

Fig. 3 Gilded areas: a micrograph of red preparation and traces of gold on the background; $\mathbf{b}$ XRF spectra of gold and red

with the used microscope. The direct XRF analysis of these spots suggests that the purple colour is due to residues of gold gilding. Indeed, previous studies reported on the purple colour of gold nanostructures (AuNPs) [7]. The same observations have been made on ivory artefacts serving as a marker of the former gilding [8].

The grey coats of the central rider figure and the rider to his right also have traces of metal decoration. Microscopy image shows metal shine at the edges of the cracks in the area of the grey dress suggesting the 
presence of a metal underlay covered with paint (Fig. 3d). XRF analysis of these areas revealed gold and silver $(\mathrm{Ag})$ (Fig. 3e) suggesting either a gold-silver alloy used for gilding or a double layer of gold leaf over silver leaf. The use of the gold-silver gilding under the grey paint is likely to attain a special effect to the paint surface. The area of the grey coat shows linear incisions made with a sharp tool. This points out at the decorative technique sgraffito $[9,10]$ consisting in application of an opaque paint layer on top of a metal layer with subsequent scraping off the former. The exposed in such a way metal layer intends to create the effect of precious textiles.

\section{Red}

Microscopy observations of the red areas revealed a mixture of a pigment with angular coarse crystals and a red-orange pigment with much smaller particles. The XRF spectra taken from the red spots are dominated by $\mathrm{Hg}$ and $\mathrm{Pb}$ lines suggesting cinnabar $(\mathrm{HgS})$ and a leadcontaining pigment (Fig. 4). The latter is likely minium as no evidence of lead white particles was detected. The use of minium and cinnabar mixture for red tones in historical paintings was a common practice in the past. It is not only due to economic factors as minium was a cheaper and more available pigment than cinnabar; but also probably due to confusion about the medieval terminology [11].

Another type of red was identified on the red shirt of the figure between the two main horsemen. The XRF spectrum from this area shows intense Fe lines suggesting iron red (Fig. 4). It is likely red iron oxide, but not ochre

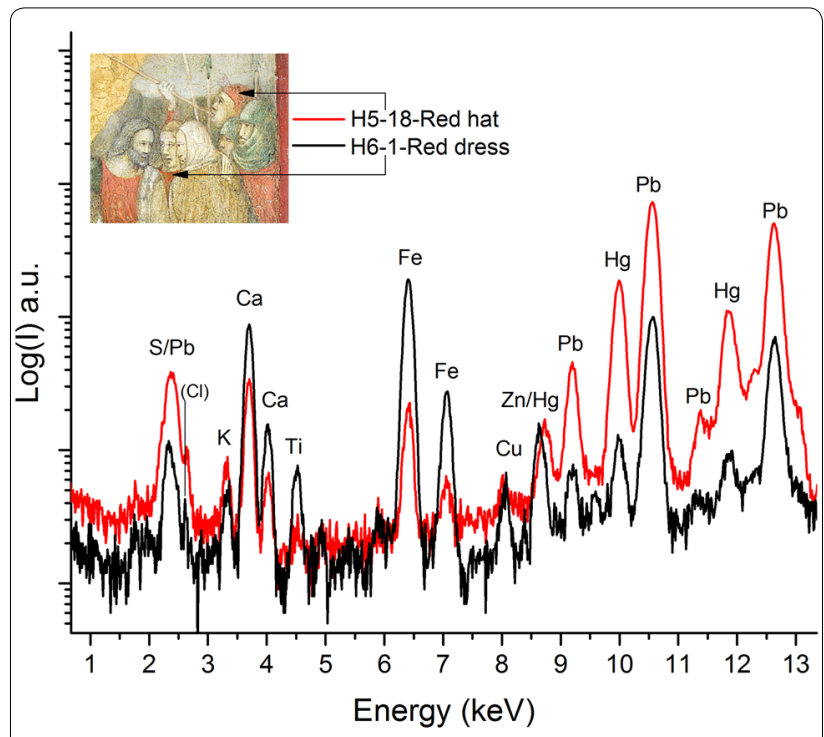

Fig. 4 XRF spectra of two red areas as no $\mathrm{Si}$ or $\mathrm{Al}$ lines are present. The low intensity of $\mathrm{Hg}$ and $\mathrm{Pb}$ lines suggests that cinnabar and minium are not the main components of the pigment mixture, but rather added to red iron oxide to attain a brighter tone.

It is also noteworthy that the more precious mixture of minium and cinnabar is applied on the main figures of the painting, whereas red iron oxide is detected on a figure playing a less important role in the painting composition such as the figure between the two horsemen.

\section{Blue and green}

Microscopy observations of the green areas allowed to detect a mixture of two pigments. One appears as coarse, deep-blue crystals and the other appears as light, translucent, green crystals of smaller size (Fig. 5a). Also the blue pigment mostly occurs on the dark shades of the dress, whereas the green pigment is used for the light shades. The XRF spectra taken from various spots on the green dress are dominated by $\mathrm{Cu}$ lines (Fig. $5 \mathrm{~b}$ ). The most widely used copper green and blue pigments available at the time of the painting are malachite $\left(\mathrm{Cu}_{2} \mathrm{CO}_{3}(\mathrm{OH})_{2}\right)$, azurite $\left(\mathrm{Cu}_{3}\left(\mathrm{CO}_{3}\right)_{2}(\mathrm{OH})_{2}\right)$ and verdigris $\left(\mathrm{Cu}\left(\mathrm{CH}_{3} \mathrm{COO}\right)_{2} \cdot \mathrm{H}_{2} \mathrm{O}\right)$. More rarely identified copper blue and green minerals that can be found in the pigment context are copper silicates such as chrysocolla $\left((\mathrm{Cu}, \mathrm{Al})_{2} \mathrm{H}_{2} \mathrm{Si}_{2} \mathrm{O}_{5}(\mathrm{OH})_{4} \cdot \mathrm{n}\left(\mathrm{H}_{2} \mathrm{O}\right)\right)$ and copper chlorides such as atacamite and paratacamite (common formula $\left.\mathrm{Cu}_{2} \mathrm{Cl}(\mathrm{OH})_{3}\right)$. Additionally, lapis lazuli $\left((\mathrm{Na}, \mathrm{Ca})_{8} \mathrm{Al}_{6} \mathrm{Si}_{6} \mathrm{O}\right.$ $\left.{ }_{24}(\mathrm{~S}, \mathrm{SO})_{4}\right)$, comprised of low- $\mathrm{Z}$ elements and, therefore, hardly detectable with XRF, can be considered. A low intensity $\mathrm{Cl}$ line, indeed, can be observed in XRF spectra of the green areas. However, chlorine is also present on the majority of spectra taken from other areas of the icon. Thus, its detection by XRF is likely related to contamination rather than the presence of atacamite. FTIR spectra taken in diffuse mode demonstrate strong bands at 2500 and $1795 \mathrm{~cm}^{-1}$ corresponding to, respectively, $\mathrm{v} 1+\mathrm{v} 3$ and $\mathrm{v} 1+\mathrm{v} 4$ combination bands of $\mathrm{CO}_{3}$ (Fig. 5c). The band around $2500 \mathrm{~cm}^{-1}$ with two maxima (2510 and $2585 \mathrm{~cm}^{-1}$ ) confirms the presence of azurite and at the same time rejects malachite, whose maxima would appear at 2420 and $2540 \mathrm{~cm}^{-1}$. The possible use of lapis lazuli can also be excluded by FTIR as no characteristic $\mathrm{Si}-\mathrm{O}$ or $\mathrm{CO}_{2}$ bands at, respectively, 900-1100 and $2340 \mathrm{~cm}^{-1}$ are present [12]. The absence of silicate bands also excludes chrysocolla. The detection of verdigris with FTIR in the presence of binders and varnishes is complicated [13], due to the overlap of the diagnostic acetate band at $1560-1610 \mathrm{~cm}^{-1}$. However, the bluish-green colour and the morphology of the pigment particles are strong arguments in favor of verdigris. 

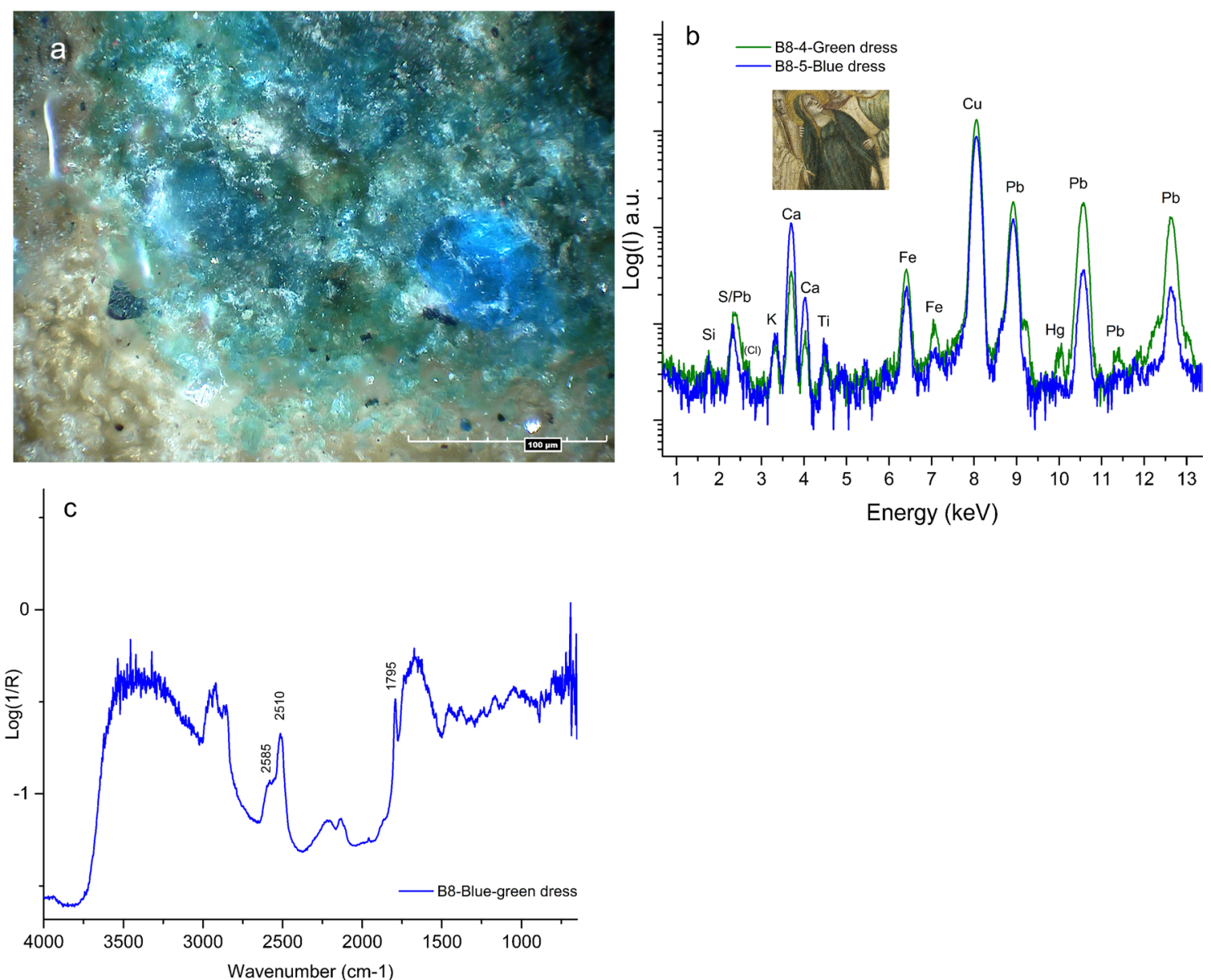

Fig. 5 Analysis of green-blue area of Mary's dress: a micrograph; b XRF spectrum; c FTIR spectrum
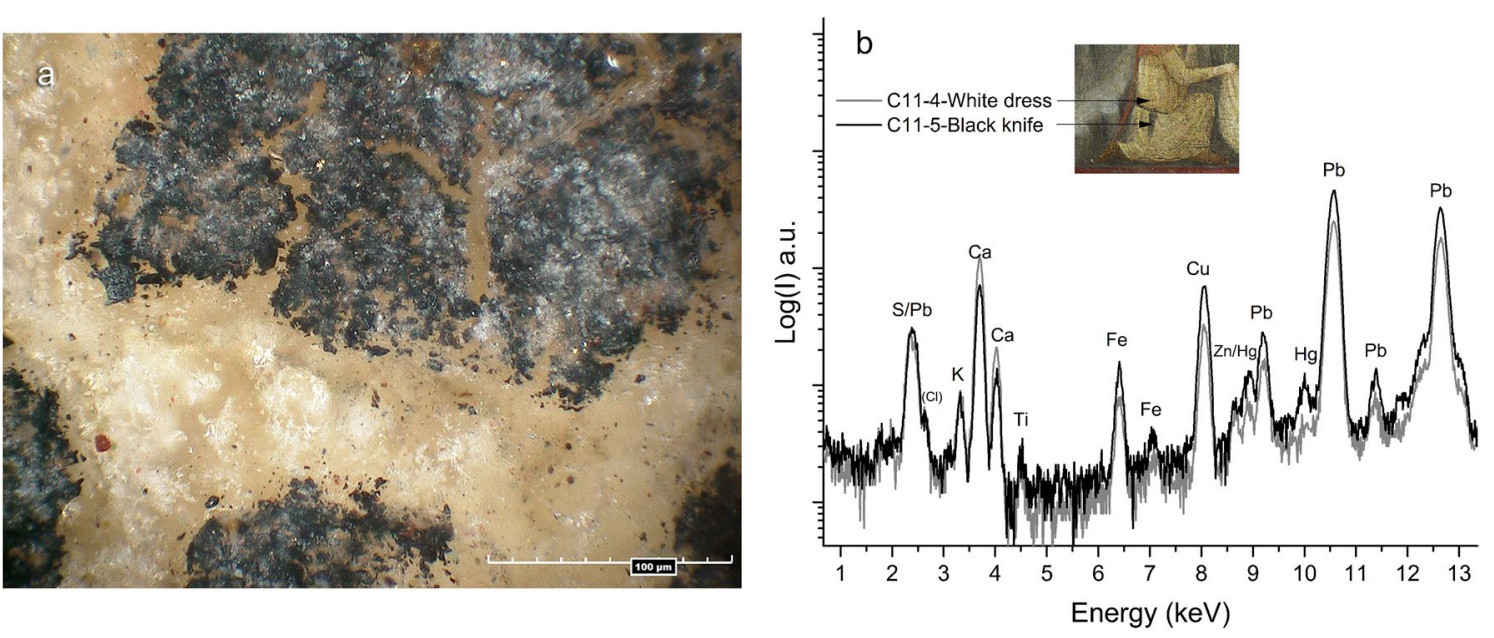

Fig. 6 Analysis of black areas: a micrograph taken from the area of the black knife; $\mathbf{b}$ XRF spectrum spectrum of the black pigment 


\section{Black, grey and brown}

The black pigment has coarse particles of irregular shape resembling the appearance of organic black pigments such as char or coke (Fig. 6a). This assumption is also supported by the IR test, which revealed an IR opaque material for the black tones (Fig. 8b). The XRF analysis also identified iron in the black tones (Fig. 6b) suggesting that it is present in the form of black iron oxide, magnetite $\left(\mathrm{Fe}_{3} \mathrm{O}_{4}\right)$. The use of ivory black can be excluded as no P lines are present in XRF spectra. The same black pigment is used in mixture with the white pigment for grey areas. For the brown colour, a mixture of the black pigment (magnetite + carbon black) and a red pigment was used. The latter appears under microscope as a mixture of coarse angular red crystals and red-orange particles of smaller size suggesting a mixture of cinnabar and minium found on the red areas of the painting. It is also supported by XRF analysis, which identified Fe, Hg and $\mathrm{Pb}$ on the brown spots analysed.

\section{Yellow}

The yellow pigment of Magdalene's dress has coarse translucent particles (Fig. 7a). XRF analysis identified Sn on all spots within the dress area (Fig. 7b). The presence of both Sn lines at 25.3 and $28.5 \mathrm{keV}$ allows to avoid the confusion with the sum peak of $\mathrm{Pb}$ at $25.2 \mathrm{keV}$ [14] and conclude on a tin-containing yellow pigment such as lead-tin yellow $\left(\mathrm{Pb}_{2} \mathrm{SnO}_{4}\right.$ (Type $\left.\mathrm{I}\right)$ and $\mathrm{Pb}(\mathrm{Sn}, \mathrm{Si}) \mathrm{O}_{3}$ (Type II)). This pigment was widely used in the Renaissance time, however, only a few studies reported on leadtin yellow found on paintings of the XIV century [15], whereas there is no documented evidence of its earlier use.

\section{Flesh tones}

The flesh tones are mainly obtained with white pigment. Admixtures of a dark red pigment with angular crystals of up to $10 \mu \mathrm{m}$, a yellow pigment with coarse particles and a green pigment with angular coarse crystals are also observed on microscopy images. The pigments were identified by XRF analysis to be lead white (the main component), iron yellow, lead-tin yellow, cinnabar and copper green. For the dark shades, admixtures of a black pigment with variable particle shape and size are detected. The XRF analysis did not detect any element indicative of the black colour suggesting an organic black pigment similar to the one used for the black as discussed above.

\section{Analysis of interventions}

The painting surface is damaged with a lot of cracks likely due to the adhesion deterioration. Simple visual examination of the panel reveals dramatic damages of the painting under study. Among them, two long cracks in the wooden support visible on the X-ray image (Fig. 8a) and several large areas on the back side, where the ground layer is missing. These damages are likely due to the movement of the wood because of aging. Further microscopy observations also revealed that the pictorial layer of the main composition also suffered from the movements of the support.

The pictorial layer presents a network of horizontal cracks and some multidirectional cracks. The scientific images show that the painting layer is very heterogeneous and it is confirmed by the microscopic examination. The painting layer is extensively worn with a lot of lacunae.
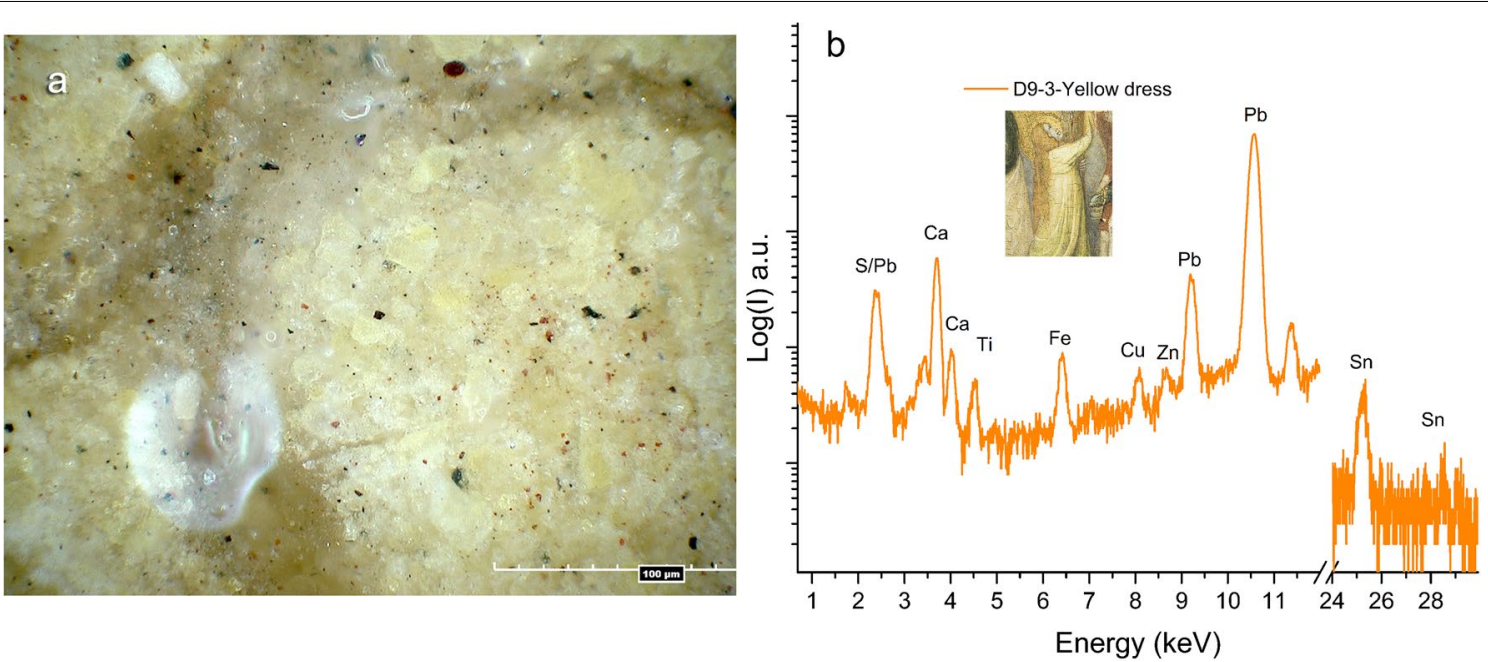

Fig. 7 Analysis of yellow areas: a micrograph taken from the area of Magdalene's dress; $\mathbf{b}$ XRF spectrum of the yellow pigment 

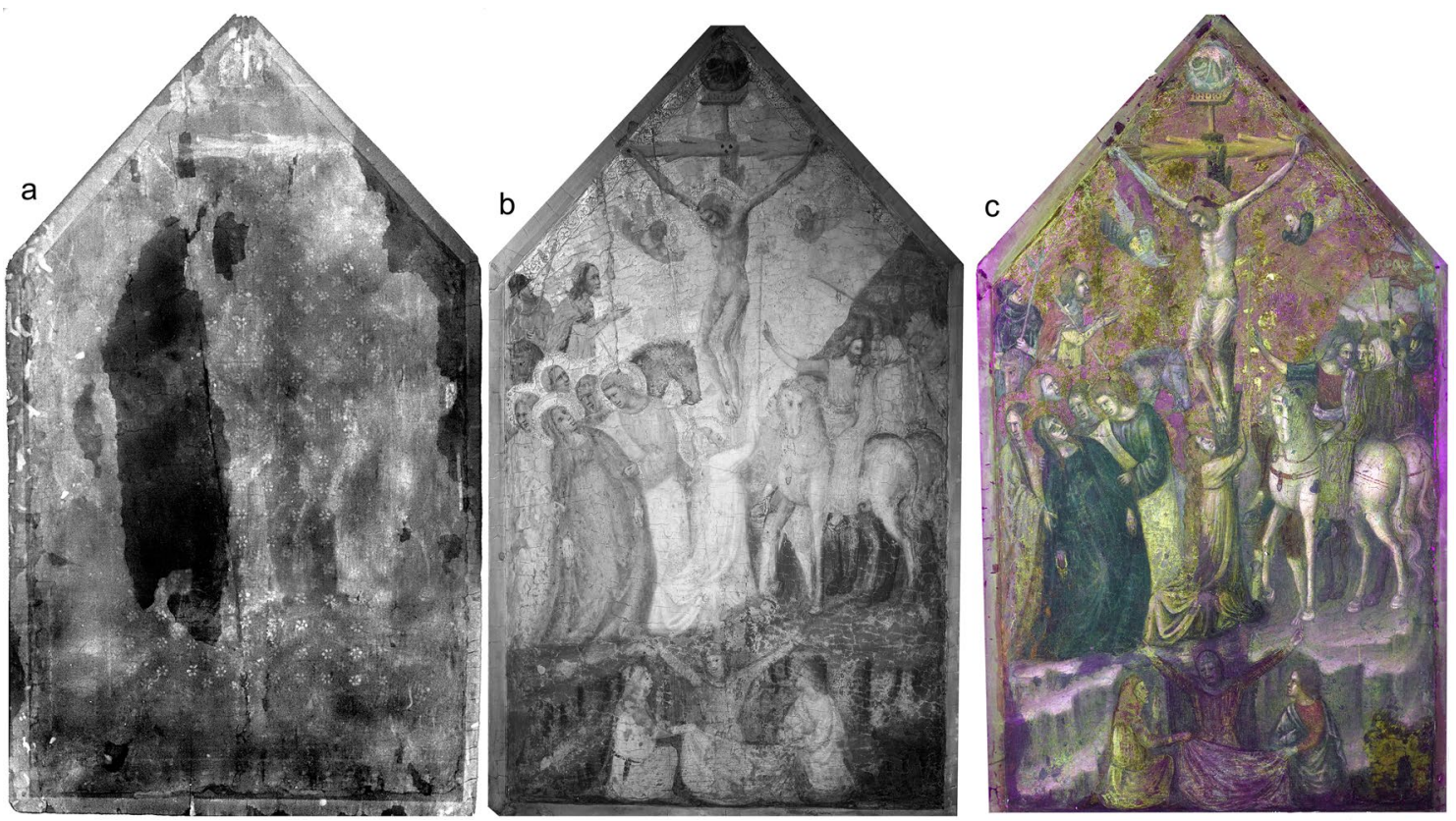

Fig. 8 Crucifixion: a XRR image; b IRR image and c UV image

Close microscopy observations of the painting's surface revealed the presence of a transparent organic material inside the cracks. It might point out at fixing of the pictorial layer by applying an adhesive to the surface, which then penetrated into the cracks and the paint layer. If it was a protein glue or wax resin, these materials were applied warm with subsequent exertion of slight pressure on the surface with a small heated spatula. Alternatively, the transparent material might be a varnish. Unfortunately, it is not possible to determine the precise nature of the adhesive materials only by noninvasive methods used in the present study. Further destructive analysis of paint samples might shed light on the nature of the conservation materials used.

Overall, the painting surface represents a lot of repaints of small scale, such as inpainting of cracks, and also of large scale, such as overpainting of some elements of composition.

\section{The most recent interventions}

The most straightforward and fast way used to evaluate painting's condition is illumination with UV light. However, this test is not sensitive to restorations made earlier than a few decades ago. The UV image of the Crucifixion (Fig. 8c) demonstrates several dark areas corresponding to the most recent interventions. Those include a few retouchings of the red frame, Christ's head, the grey background in the lower left corner, Mary Magdalene's dress and a large area at the bottom.
Close microscopy observations of the bottom of the painting also reveal false craquelure. Figure $9 \mathrm{a}-\mathrm{c}$ shows micrographs taken from the area of the sheet at the bottom revealing that the cracks are deliberately painted with a fine brush using a black pigment. This was likely intended to create the illusion of the real aged craquelure on the recently restored area, which is not yet distorted with such damages as cracks or tears.

According to XRF data, the dark areas of the UV image are characterized by elevated $\mathrm{Ti}, \mathrm{Zn}, \mathrm{Cd}, \mathrm{Se}$ and $\mathrm{Cr}$ counts corresponding to the presence of titanium white, zinc white, cadmium red/yellow and chromium green. Example XRF spectrum taken from the area of the green coat of the first figure from the right on the lower foreground is shown in figure (Fig. 9d). These pigments are known to be present in the modern pigment palette, which confirms a very recent restoration of these areas.

\section{Inpainting of cracks and the tratteggio technique}

Further investigations by microscopy and XRF suggested that there are other areas of interventions in addition to those identified with the UV test. The areas of apparent interventions do not appear dark under UV light, suggesting that they had been done earlier.

The microscopic observations suggest two types of these interventions. The first one is mostly related to inpainting of cracks. Figure 10 shows example micrographs taken from the areas of Mary's bluishgreen dress (Fig. 10a), the face and hands of the standing 

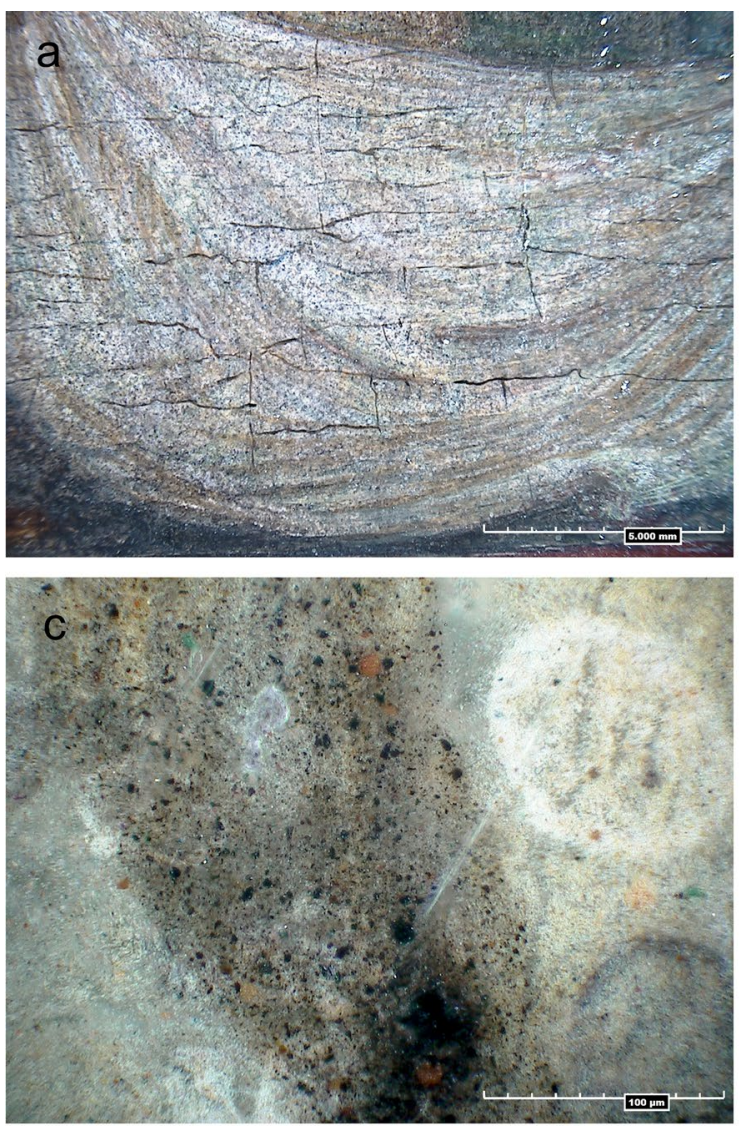
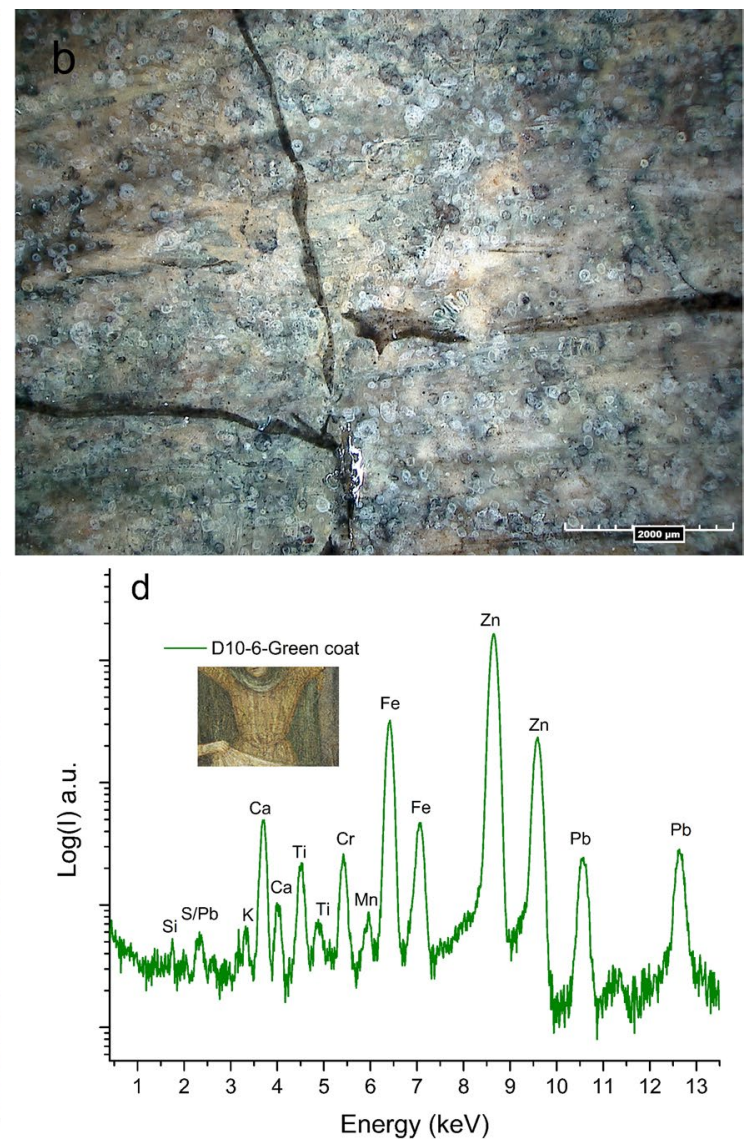

Fig. 9 Analysis of the area at the bottom, appearing dark on UV: a-c micrographs showing false craquelure; $\mathbf{d}$ XRF spectrum of the green area

figure on the left of Virgin Mary (Fig. 10b, d, respectively) and the dark background between the legs of the horses (Fig. 10c). The microscopy images show the obvious difference in the coarse angular crystals of the original pigments and the evenly fine particles of the material used to fill the cracks. The latter is inconsistent with the hand-ground pigments of the period of the painting and rather points out at a relatively recent intervention. The inpainting is made with a mixture of various pigments, whose resulting colour intends to reproduce the colour of the original paint. In this case, the brush strokes mostly run along the cracks (Fig. 10a-c) or, more rarely, the paint layer runs over the entire damaged area (Fig. 10d). These interventions are aimed to hide the damages by matching in colour the original parts of the painting and bringing the surface level to the level of the original painting without any visual effects.

The second type of interventions detected with microscopy is related to restoration of larger areas by filling gaps in pictorial layer with juxtapositions of brushstrokes. Figure 11 shows example micrographs taken from the areas of Mary's green dress (Fig. 11a), the grey horse (Fig. 11b), the white dress of John the Evangelist supporting Virgin Mary (Fig. 11c) and the red shirt of the first figure from the right on the lower foreground (Fig. 11d). As seen in these images, the brushstrokes are consistent in their shape and direction, but alternate in the colour and density. The latter allows to avoid recreating the original colour of the area under restoration. Instead, the final visual effect of recreation of the original colour is achieved by combination of brushstrokes of complementary colours. The areas restored in such a way are easily detectable on close inspection either with the naked eye or with microscopy, but can hardly be distinguished, when looking from a distance. This type of restoration, known as tratteggio, was invented in the $1950^{\prime} \mathrm{s}$ and is intended to reinstate the overall content of the area, at the same time making clear differentiation from the surviving original. 

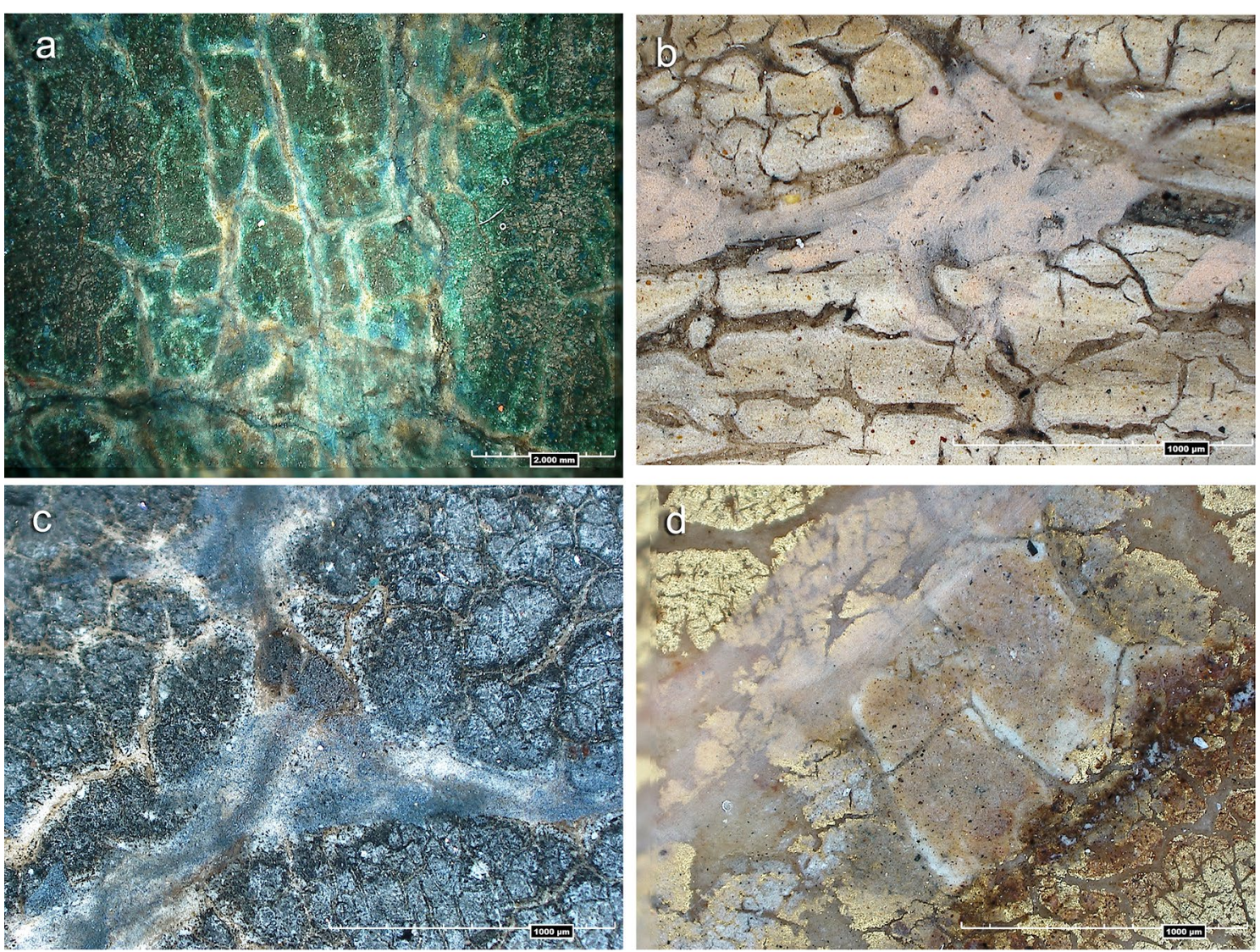

Fig. 10 Micrographs of various areas showing examples of inpainting

\section{XRF analysis of interventions}

The areas of interventions identified with digital microscopy and the UV imaging were examined with multiple point XRF analysis (Fig. 12). The selection of spots for the point XRF analysis was based on the results the microscopy, UV and XRR tests described above. The following elements were identified and the possible pigment suggestions were made: $\mathrm{Ti}$ for titanium white $\left(\mathrm{TiO}_{2}\right)$, simultaneous presence of $\mathrm{Ba}$ and $\mathrm{Zn}$ for lithopone $\left(\mathrm{BaSO}_{4} \cdot \mathrm{ZnS}\right), \mathrm{Zn}$ for zinc white $(\mathrm{ZnO}), \mathrm{Cd}$ and $\mathrm{Se}$ for cadmium red (CdSe) and yellow (CdS), Cr for chromium green $\left(\mathrm{Cr}_{2} \mathrm{O}_{3}\right)$, Co for cobalt blue $\left(\mathrm{CoAl}_{2} \mathrm{O} 4\right), \mathrm{Sb}$ for an antimony-containing yellow.

The high $\mathrm{Ti}$ counts can be observed in the areas appearing dark on UV image (Fig. 8b) as well as outside suggesting the use of titanium white for both the most recent restorations and for the earlier ones. Unlike in titanium white, lithopone is present in a much lesser extent on the Crucifixion. The areas with elevated $\mathrm{Ba}$ and $\mathrm{Zn}$ counts include a spot on the red frame, the central figure at the lower foreground, the hands of Mary and the person identified as Longinus, a spot on the grey horse, the restored gold gilded background under the cross, the green coat and the spear of person on the left. Comparing the Fig. 12a-c, it can be noticed that only a few areas demonstrate elevated counts of both $\mathrm{Ti}$ and $\mathrm{Ba} /$ $\mathrm{Zn}$. This observation could be explained by the presence of two layers of restoration: the earlier restoration with lithopone and the later restoration with titanium white. The analysis of $\mathrm{Zn}$ distribution (Fig. 12c) suggests that zinc is present not only in the form of lithopone, but also as zinc white, used along with titanium white for the most recent restoration of the bottom of the composition.

The multiple point XRF analysis of Cd (Fig. 12d) correlates with the results of Se analysis (Fig. 12e), suggesting the presence of $\mathrm{CdSe}$. The highest $\mathrm{Cd}$ and $\mathrm{Se}$ counts can be seen in the area of the red frame at the bottom of the Crucifixion suggesting that it was restored with cadmium red. Other areas showing elevated $\mathrm{Cd}$ and Se counts coincide with the flesh tones and the yellow areas of the Crucifixion including the restoration of gold gilded area near Christ's proper right hand. The use of 

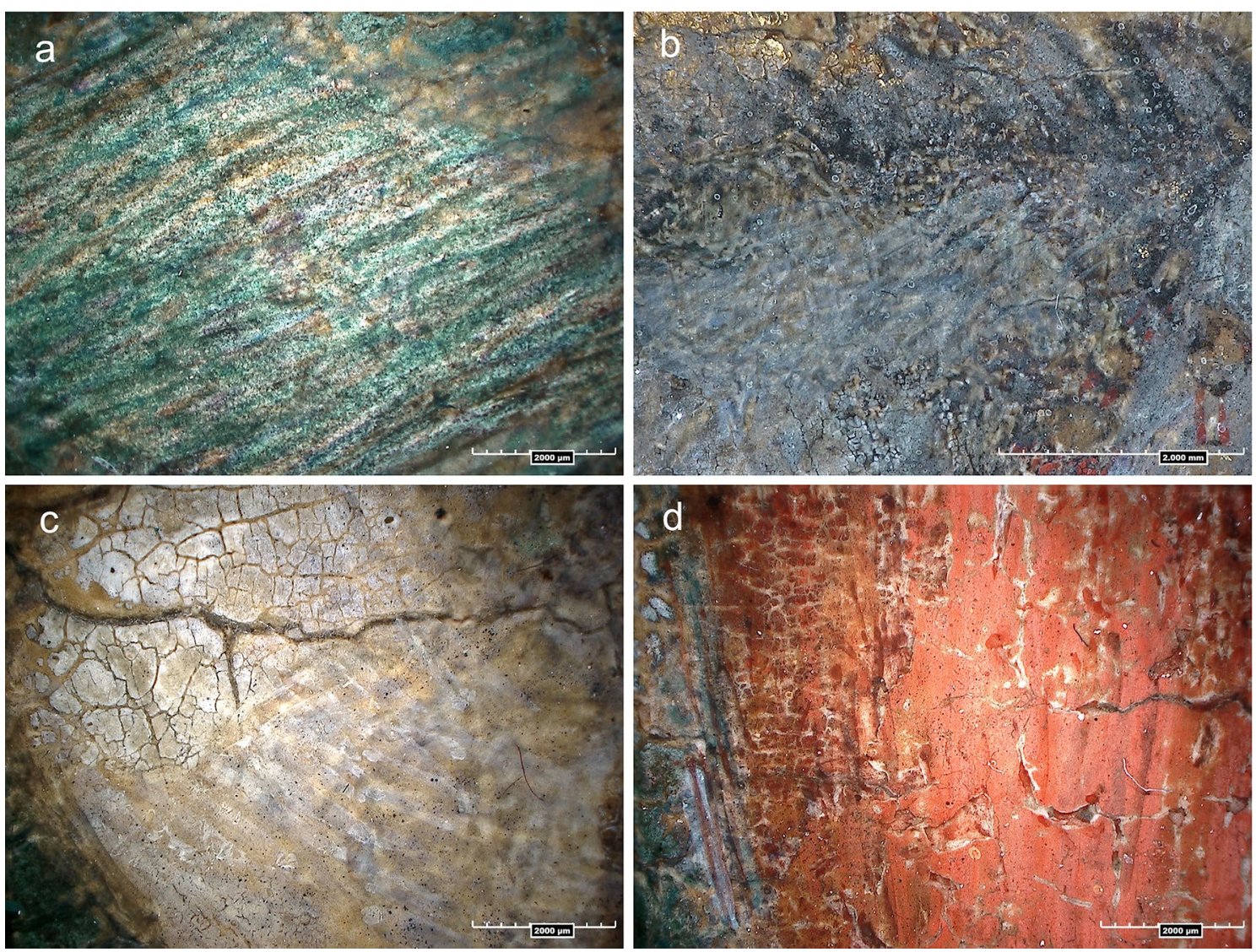

Fig. 11 Micrographs of various areas showing examples of the tratteggio technique

both pigments, cadmium yellow (CdS) and cadmium red (CdSe) on these areas can be attested by microscopy observations, which show mixture of the bright yellow and red particles of fine size.

Chromium is detected by XRF analysis on greenblue areas (Fig. 12f) suggesting their restoration with chromium green. Those areas include the green-blue garments as well as the tip of the spear held by one of the soldiers from the group to the left of Christ's cross. As mentioned above, a blue pigment with fine particles was used for inpainting cracks of the original green-blue and grey areas. Multiple point XRF analysis suggests that this pigment is cobalt blue as elevated Co counts can be seen on the green-blue areas and the grey area at the bottom (Fig. 12g). The absence of As lines in XRF spectra allows to exclude smalt, whose use in historical paintings preceded the use of cobalt blue.

Figure $12 \mathrm{~h}$ shows elevated $\mathrm{Sb}$ counts in the following areas: yellow cuffs of person on the left, hair of person above Mary, the dress of person to the right from the latter, the dress of person on the left from Mary, flesh tones and wings of angel, the red flag and the spear on the right side. The detection of Sb suggests an antimonybased yellow pigment such as lead-antimony oxide $\left(\mathrm{Pb}_{2} \mathrm{Sb}_{2} \mathrm{O}_{7}\right)$, lead antimony tin oxide or lead antimony zinc oxide [16].

The pigments detected on the restored areas allow to narrow the presumable time range of these interventions. Lithopone was in use during the second half of the nineteenth century and in the 1920 's it was replaced by titanium white. Zinc white has been known since antiquity, but has been used as a pigment for paintings since the middle of the nineteenth century [17]. Antimony-based pigments were identified in paintings dating from the seventeenth century and it reached the peak of its use between 1750 and 1850 [18]. Cobalt blue has been in use since the beginning of the nineteenth century [19]. Cadmium yellow and red pigments became commercially available in the beginning of the twentieth century [20].

It must be noted that in Crucifixion, lithopone is always found on spots retouched by inpainting, whereas 


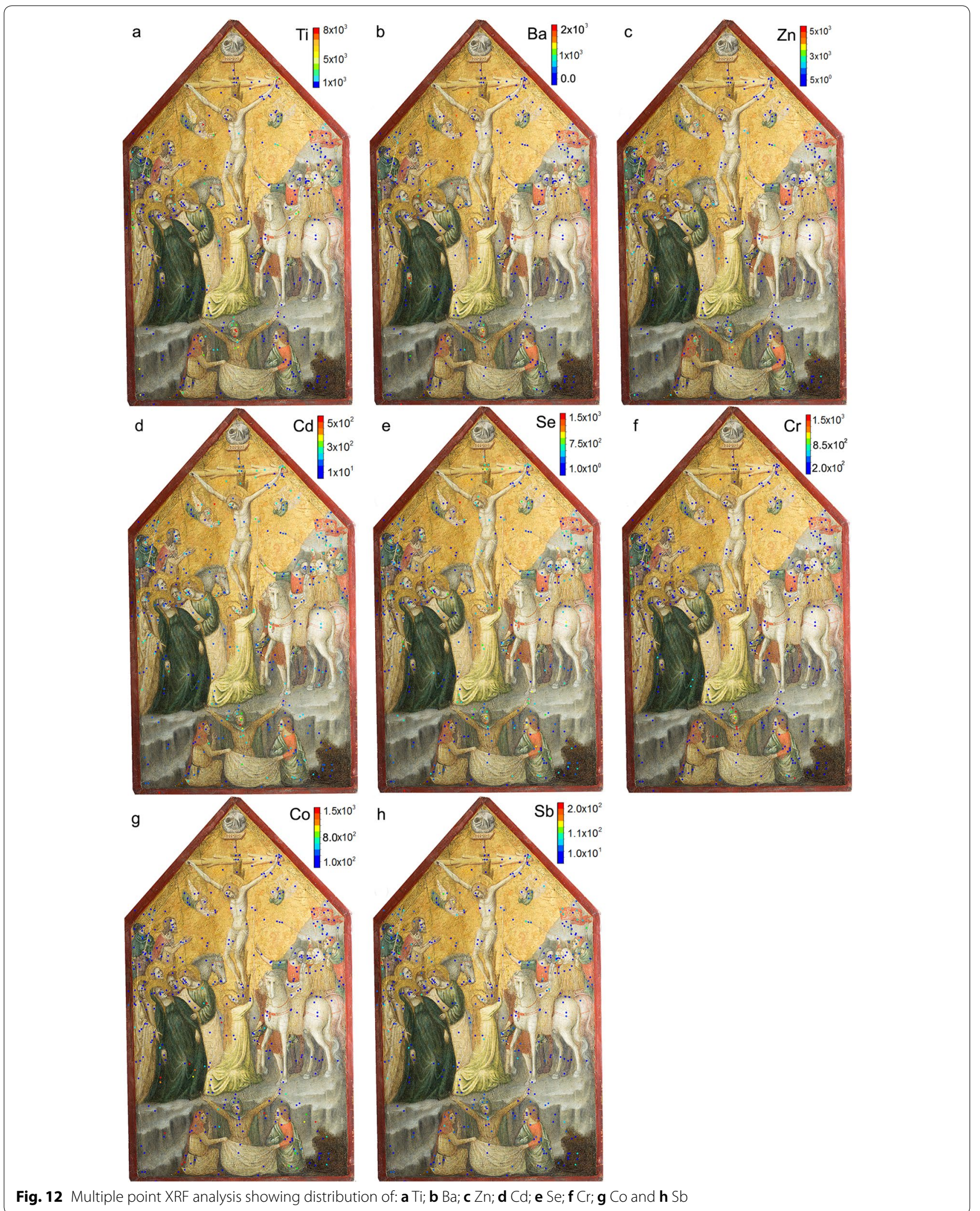


Table 1 Suggested pigments based on non-invasive examination of the original areas

\begin{tabular}{|c|c|c|}
\hline Colour & Area & Suggested pigments \\
\hline \multirow[t]{3}{*}{ White } & Ground, front side & Calcite; admixtures of gypsum, silicate material and lead white \\
\hline & Ground, back side & Gypsum; admixtures of calcite \\
\hline & White elements & Lead white \\
\hline \multirow[t]{3}{*}{ Gold } & Background & Water gilding \\
\hline & Inscription SPQR, stirrups, bridle, belt of horse & Gold leaf applied directly on pictorial layer \\
\hline & Coats and hood of horsemen & Gold-silver alloy or double metal layer covered with lead white paint; sgraffito technique \\
\hline Flesh tones & Skin & $\begin{array}{l}\text { Lead white; admixtures of iron yellow, lead-tin yellow, cinnabar, copper green; carbon } \\
\text { black for dark shades; no green preparatory underlay }\end{array}$ \\
\hline \multirow[t]{2}{*}{ Red } & Red frame, Garments, flag & Cinnabar + minium \\
\hline & $\begin{array}{l}\text { Shirt of person between the two main } \\
\text { horsemen }\end{array}$ & Red iron oxide, admixtures of cinnabar and minium \\
\hline Blue-green & Garments & Azurite + copper green \\
\hline Black & $\begin{array}{l}\text { Contours of figures, details, knife of first figure } \\
\text { from the left on the lower foreground, dark } \\
\text { shades }\end{array}$ & Black iron oxide, carbon black \\
\hline Brown & Hair of figures, legs of horses & Black iron oxide, carbon black, cinnabar, minium \\
\hline Yellow & Mary Magdalene's dress & Lead-tin yellow \\
\hline
\end{tabular}

titanium white is found mostly on spots retouched by the tratteggio technique. This observation allows to distinguish two more phases of interventions: the earlier ones by inpainting, probably dating to the end of the 19th-beginning of the twentieth century; and the later ones by tratteggio, dating to the second half of the twentieth century.

\section{Missing details in the lower corners}

A closer observation of the lower left and the right corners of the panel revealed that it is a crude and unrefined overpainting attempt (Fig. 13). Microscopy images of these areas show bright, shiny material (Fig. 13a) identified by XRF as gold leaf and overpainted with the brown paint (Fig. 13b). Closer observations also allow to detect a red layer underlying the gold leaf, probably a red bole.

In order to make an informed working hypothesis on the matter, we turned to the close comparison of the composition with a Crucifixion painted by another important member of the Rimini group, Pietro da Rimini, dated in the 1310 s. Pietro's version (Fig. 14) is particularly close to Giovanni Baronzio's panel [21, 22]. The key difference concerns the comparison of the lower parts of the two paintings. In Pietro's Crucifixion, four kneeling male figures are also gathered around a stretched sheet and other articles of clothing. This scene represents the division of Christ's clothes between soldiers. The central figure is represented throwing his hands in excitement looking at the loot. In each corner of the panel, a figure is represented emphatically turning away from the tragedy of the main event.

Although Giovanni Baronzio's version certainly follows the same compositional models, its details present differences thus affecting the painting's visual narrative. The foreground figures are not engaging in the looting of Christ's clothes. The lack of additional figures in the corners provides a focus on the three figures which offer a different narrative.

Unfortunately, it was not possible to identify, what was originally painted at the particular area of the composition as neither IRR nor XRR imaging revealed any pictorial details that could inform on the visual content. Future analysis by macro-XRF, an alternative non-invasive technique nowadays widely used for painting analysis, could shed light on these hidden elements. We can only hypothesize about what might have existed in the particular parts of the painting. What is important is to highlight the need for the specific overpainting which could be the result of the choices of the panel's new owners, or simply efforts to restore damage thus offering the pretext for a different 

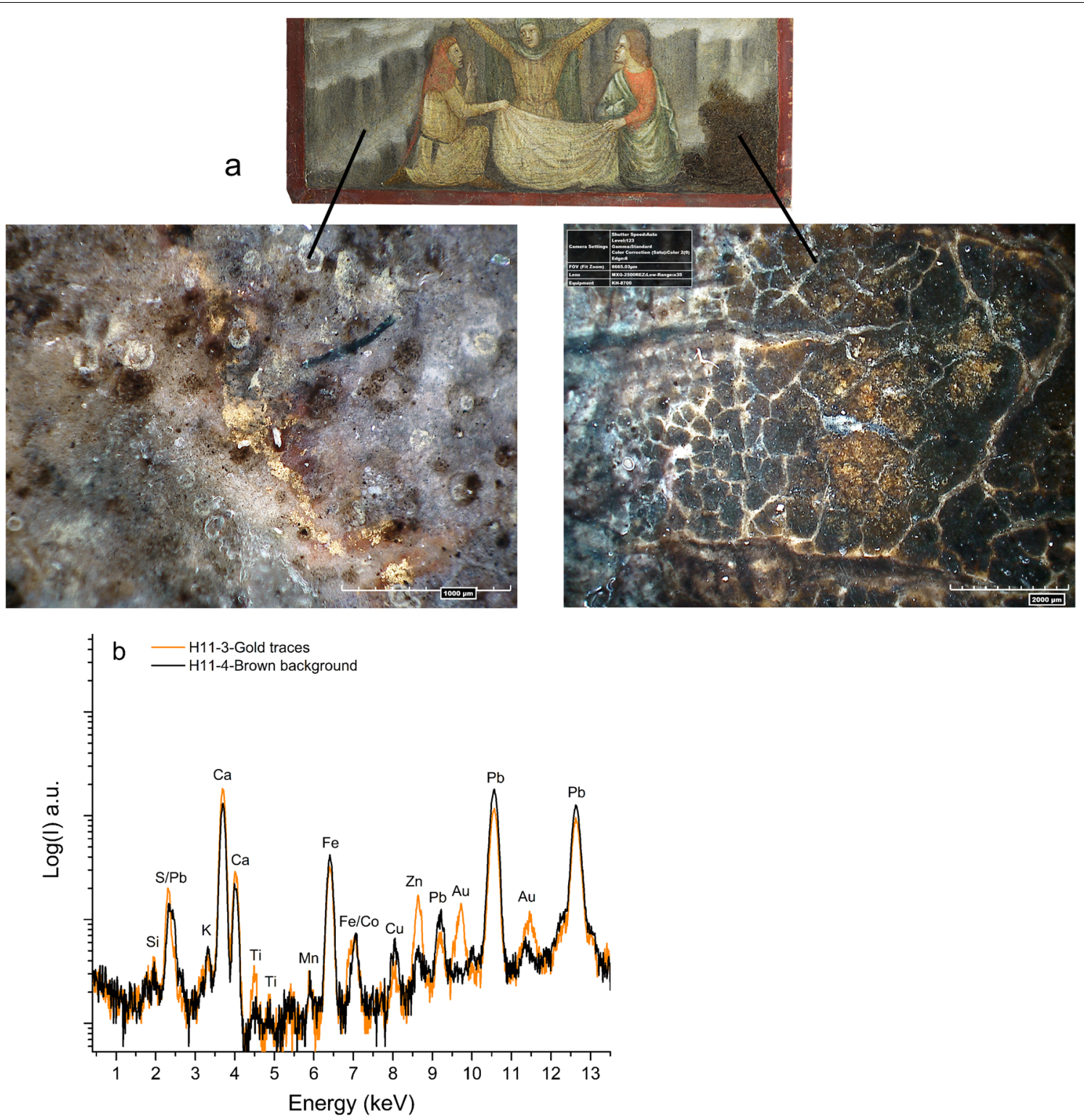

Fig. 13 Lower part of the Crucifixion: a micrographs showing the underlying layer of gold; $\mathbf{b}$ XRF spectrum

interpretation of the scene's narrative. 'Corrective' interventions are a major chapter in Art History research. They reflect changes in taste and style, ideological and political priorities; more importantly they constitute key chapters in the long history of works of art, especially in the case of objects of religious cult like Giovanni Baronzio's Crucifixion panel.

\section{Conclusions}

The Crucifixion painting panel attributed to Giovanni (da Rimini) Baronzio was studied by non-invasive analytical methods. The suggested original pigments are summarized in Table 1 . This study allowed the identification of the original pigments and techniques, which were found to be consistent with the materials and methods of the period of the painting. The pigment palette consists of lead white, minium, cinnabar, azurite, copper green, iron containing pigments, carbon 


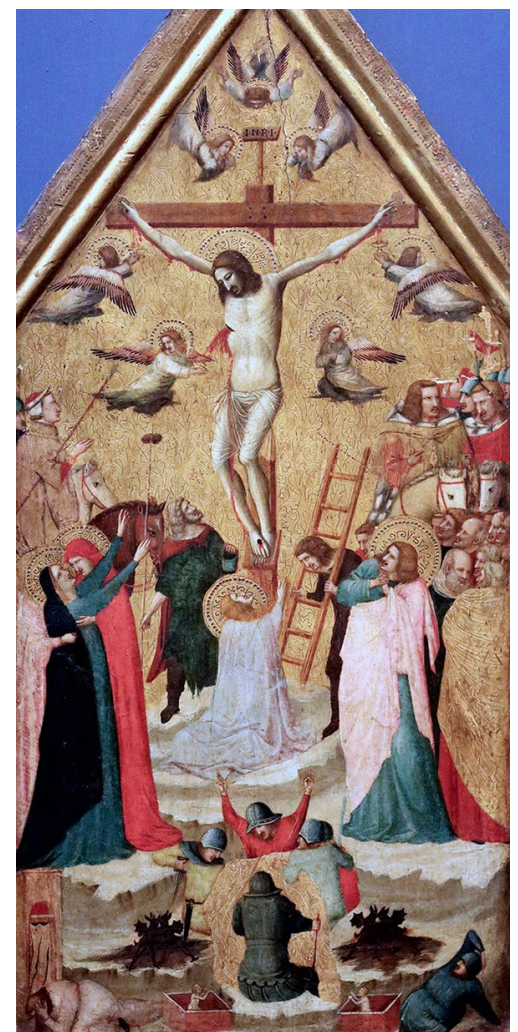

Fig. 14 The Crucifixion by Pietro da Rimini (active in the second quarter of the fourteenth century), Hamburg Kunsthalle [21, 22]

black and lead-tin yellow. The gilding was executed with the gold leaf technique applied on red bole. Some areas demonstrate the use of sgraffito technique (lead white applied on gold-silver layer). The panel's overall state of conservation was evaluated revealing that the painting bears the evidence of a series of interventions. The combined use of digital microscopy, UV imaging and multiple point XRF analysis allowed to conclude on at least three episodes of interventions. The oldest one is attributed to the end of the nineteenth - beginning of the twentieth century and features inpainting of cracks and damaged areas as well as the use of lithopone, cobalt blue and an antimony-containing pigment. The next episode of interventions is attributed to the second half of the twentieth century, possibly related to the transfer of the work from the Hahn to the Sestieri and the London collections, and features the tratteggio technique and the use of titanium white, cadmium red and yellow and chromium green. Finally, the most recent interventions were detected by the UV imaging and are featured by the use of titanium white, zinc white, chromium green and cadmium yellow and red. Although the present study offers the evidence of three episodes of intervention made to the original composition, we do not exclude the possibility of other ones, whose detection is outside the capacity of the applied analytical methodology. The combined use of microscopy and point XRF analysis allowed to detect traces of previously existing pictorial details in the lower corners of the composition, which are absent in the current composition. The close comparison of the studied Crucifixion by Giovanni da Rimini Baronzio with the Crucifixion by Pietro da Rimini allowed the hypothesis that the original painting composition was significantly altered as a result of multiple interventions.

\section{Abbreviations}

FTIR: Fourier transform infrared spectroscopy; XRF: X-ray fluorescence spectroscopy; UV: Ultraviolet; XRR: X-ray radiography.

\section{Acknowledgements}

The authors would like to thank Dr. Andreas Pittas for entrusting them to analyse the Crucifixion. We also thank Ropertos Georgiou for providing the UV and VIS images. The authors are thankful to the Mediterranean Hospital of Limassol for the XRR test.

\section{Authors' contributions}

SG performed the data acquisition, analysis and interpretation. She was the lead author of the article's text. NB was responsible for the art-historical description and analysis of the paintings, he wrote and edited the related parts of the article. SH was responsible for setting-up the methodological and scientific framework. DLM contributed to the interpretation of interventions and advices on the analysis of restorations. All authors edited the final manuscript. All authors read and approved the final manuscript.

\section{Funding}

The study did not receive any financial support

\section{Availability of data and materials}

All the raw data can be accessed at https://drive.google.com/drive/folde rs/1PtMNo2RcjTvcb7TxF_gHFK7-40hABJy4?usp=sharing.

\section{Competing interests}

The authors declare that they have no competing interests

\section{Author details}

${ }^{1}$ Andreas Pittas Art Characterization laboratories, APAC, Science and Technology in Archaeology and Culture Research Center, STARC, The Cyprus Institute, Nicosia, Cyprus. ${ }^{2}$ Center for the Research and Restoration of the Museums of France-C2RMF, Paris, France.

Received: 31 July 2020 Accepted: 22 September 2020

Published online: 08 October 2020

\section{References}

1. Casu S. Giovanni baronzio: crucifixion. In: Casu S, editor. The pittas collection. Early Italian and Renaissance works, Vol. 2. Florence: Mandragora; 2018. p. 12-17.

2. Ferrara D, editor. Giovanni Baronzio e la pittura a Rimini nel Trecento, exhibition catalogue. Rome, 14 March-15 June. Milan: Silvana Editoriale; 2008. 
3. Benati $D$, editor. II Trecento Riminese: maestri e botteghe tra Romagna e Marche. Exhibition catalogue, Rimini, Museo della Citta, 20 August 1995-7 January 1996. Milan: Electra; 1995.

4. Boskovits M. Per la storia della pittura tra la Romagna e le Marche ai primi del 300. Arte Christiana. 1993;81:163-82

5. Volpe A. Giotto e i Riminese, Milan: Federico Motta; 2002.

6. West FE. Red lead and minium. In: Feller RL, editor. Artist's pigments: a handbook of their history and characteristics, vol. 1. London: Archetype Publications; 2012. p. 109-140.

7. Neupane MP, Lee SJ, Park IS, Lee MH, Bae TS, Kuboki Y, Uo M, Watari F. Synthesis of gelatin-capped gold nanoparticles with variable gelatin concentration. J Nanopart Res. 2011;13:491-8. https://doi.org/10.1007/ s11051-010-9971-9.

8. Spadavecchia J, Apchain E, Albéric M, Fontan E, Reiche I. One-step synthesis of collagen hybrid gold nanoparticles and formation on Egyptian-like gold-plated archaeological ivory. Angew Chem. 2014;53(32):8363-6. https://doi.org/10.1002/ange.201403567.

9. Barata C, Cruz AJ, Carballo J, Coroado J, Araujo ME. Gilding materials and techniques used in erudite and popular portuguese polychrome baroque wooden sculptures. In: Proceedings of Technart Conference 2009: Non-destructive and Microanalytical Techniques in Art and Cultural Heritage. 2009; p. 184

10. Sandu ICA, de Sá MH, Pereira MC. Ancient 'gilded' art objects from European cultural heritage: a review on different scales of characterization. Surf Interface Anal. 2011;43(8):1134-51. https://doi. org/10.1002/sia.3740.

11. Thompson DV. The materials of medieval painting. New Haven: Yale University Press; 1936

12. Miliani C, Rosi F, Daveri A, Brunetti B. Reflection infrared spectroscopy for the non-invasive in situ study of artists' pigments. Appl Phys A. 2012:106:295-307. https://doi.org/10.1007/s00339-011-6708-2.

13. Beltran V, Salvadó N, Butí S, Cinque G. Micro infrared spectroscopy discrimination capability of compounds in complex matrices of thin layers in real sample coatings from artworks. Microchem J. 2015;118:11523. https://doi.org/10.1016/j.microc.2014.09.001.

14. Namowicz C, Trentelman K, Mcglinchey C. XRF of cultural heritage materials: round-robin IV_-paint on canvas. Powder Diffr. 2009;24(2):1249. https://doi.org/10.1154/1.3132591.

15. Kuehn H. Lead-tin yellow. In: Roy A, editor. Artist's pigments: a handbook of their history and characteristics, vol. 2. London: Archetype Publications; 2012. p. 83-112.

16. Sandalinas C, Ruiz-Moreno S. Lead-tin-antimony yellow: historical manufacture, molecular characterization and identification in seventeenth-century Italian paintings. Stud Conserv. 2004;49(1):41-52. https://doi.org/10.1179/sic.2004.49.1.41.

17. Kuehn H. Zinc White. In: Feller RL, editor. Artist's pigments: a handbook of their history and characteristics, vol. 1. London: Archetype Publications; 2012. p. 169-186

18. Wainwright INM, Taylor JM, Rosamond DH. Lead antimonate yellow. In: Feller RL, editor. Artist's pigments: a handbook of their history and characteristics, vol. 1. London: Archetype Publications; 2012. p. 219-254.

19. Mayer $R$, editor. The artist's handbook of materials and techniques. New York: Viking; 1991

20. Fiedler I, Bayard MA. Cadmium yellows, oranges and reds. In: Feller RL, editor. Artist's pigments: a handbook of their history and characteristics, vol. 1. London: Archetype Publications; 2012. p. 65-108.

21. Sitt M. Pietro da Rimini, Crucifixion. In Sitt M, editor. Die Sammlungen der Hamburger Kunsthalle. I. Die Deutschen, Enlischen, Französischen, Italinischen und Spanischen Gemälde, 1350-1800. Hamburg: Hamburger Kunsthalle; 2007. p. 255-7.

22. flickr.com/photos/mazanto/29392114963

\section{Publisher's Note}

Springer Nature remains neutral with regard to jurisdictional claims in published maps and institutional affiliations.

\section{Submit your manuscript to a SpringerOpen ${ }^{\circ}$ journal and benefit from:}

- Convenient online submission

- Rigorous peer review

- Open access: articles freely available online

- High visibility within the field

- Retaining the copyright to your article

Submit your next manuscript at $\boldsymbol{\nabla}$ springeropen.com 